\title{
Ergonomic Evaluation of Drudgery Load Faced by Farm Women in Wheat Harvesting
}

\author{
Barkha Sharma $^{1}$, Shilpi Verma ${ }^{2 *}$ and Md. Mustafa ${ }^{1}$ \\ ${ }^{1}$ Programme Assistant (Home Science) and S.M.S (Horticulture), KVK, Ratlam, M.P., India \\ ${ }^{2}$ S.M.S (Home Science), KVK, Neemuch, M.P., India \\ *Corresponding author
}

\section{A B S T R A C T}

Keywords

Sickle, Drudgery, Ergonomics.

Article Info

Accepted:

26 September 2017

Available Online:

10 October 2017
A study was conducted in Ratlam distict of Madhya Pradesh. Naveen, Vaibhav and Local sickle evaluated for harvesting wheat crop with 30 farm women. Harvesting is a main drudgery prone activity which is mostly done by farm women and to solve this problem Krishi Vigyan Kendra Ratlam, as per its mandate conducted front line demonstration on "Improved Sickle" in wheat Harvesting. A technically prepared serrated sickle and Vaibhav sickle was tested on farm women to improve work efficiency and to reduce the drudgery of women.

\section{Introduction}

The role of Indian women is very important in improving the economy of the country. There are 92 million women working in agriculture and allied sector and it is about $40 \%$ of the total rural workers in India (Singh et al., 2007).

Women workers are about $25.5 \%$ the total workers in India as per census 2011. Among them cultivators are $24.9 \%$ agricultural labours are $18.5 \%$ and workers in household industry and other works are $47.2 \%$ women are important workers in agriculture. In the field of agriculture they work as female labours, farmers, co-farmers, female family, as farm managers and farm entrepreneurs (Prakash N. et al., 2014). The sickle is widely used and is a very old tool which was curved blade with a handle. It is used to cut or reap wheat crop. Sickle has two types of cutting edge i.e., plain and serrated with depth of 1 $\mathrm{mm}$. Serrated sickle is only used in wheat harvesting but plain sickle is used every were so it is more in use shearing force is used in plain sickle while fractional force is used in serrated sickle. Different industry and research organization improved serrated sickle to use in harvesting more crops (Singh 2009).

All thought the role of women in livestock production, horticulture, post-harvest operation is important but it is ignored (Sing surbhi, 2010). In post-harvest activities a women spends 38.7 hours on wheat producing per acre in one season. The post-harvest us 
spend in activities were 121.5 hours per acre for this crop (Khan et al., 2012).

Harvesting the wheat crop is a big problem for farmers/ farm women all over the world. In harvesting precaution is taken otherwise mature grain will easily detach from the ear heads/ponds as by fast working tools or machine. Women perform harvesting by local sickle with bending and squtting posture for hours together (Sing Alka, 2014).

E.g. 8-9 hours daily, large land holders use different harvesters but small and marginal farmers depend on hand tools operating labours due to various seasons. Harvesting is done in unnatural body posture for long time it increase the physiological work load of women and they face many musculo-skeletal body problems decreasing the work efficiency (Jyotsana, 2014).

Manual harvesting is very depending of labour and is full of drudgery. Tool design and used body posture therefore increases the discomfort of both healthy and less fit individuals (Sing Alka, 2014).

In present study, improved sickle of two organization were taken. Vaibhav sickle from Dr. Baba Sahab Konkan Krishi Vidyaptteh (BSKKV), Dapoli and Naveen sickle from Central Institute of Agricultural Engineering (CIAE) Bhopal.

Then the performance of local sickle and improved sickle were compared.

A science that is concerned with a fit between people and their work is known as ergonomics. This science given priority to people first thinking of their abilities and limitations, ergonomics makes sure that equipment, tasks, information and environment suit each workers (Rajendran and Reddy, 2013).
If farm women, while working experience physical and mental strain, fatigue, monotony and hardship, it is known as drudgery (Kumar et al., 2011).

This research is aimed to reduce their drudgery and increase their working efficiency by introducing improved sickle. The farm work demands women work which result is lot of fatigue and occupational health hazards added by improper posture. Improves sickle is lighter than local sickle and works in a comfortable posture (Sharma Barkha et al., 2015).

We selected Chiklana and Lasudiya Nathi Village of KVK Ratlam for this study. 30 farm women were selected who were good in traditional sickle harvesting. There women had good health. The gradation of health status was done on the basis of BMI. Garrow's (1987) classification was used for BMI scores.

Heart rate of every respondent was tried as the heart rate monitoring machine. It was switched as to record the heart rate at every minute. Five minute interval as rest was given to record the resting heart rate. Respondents were asked to do harvesting for 30 minute and heart rate was recorded at an interval of one minute each and than five minute rest was given. Then the monitor was switched off and removed. The respondents work with traditional as well as serrated and vaibhav sickle during which heart rate was recorded in rest and in working condition. The following parameters were calculated on the basis of the result of heart rate records.

\section{Brief description}

Local (plain) sickle cuts the crop stalk by impact or pulling action while improved (serrated) sickle cuts it by sawing action. Improved sickle has serrated blade, ferrule 
and wooden handle and weight duly $180 \mathrm{gm}$. Wrist fatigue is less and the drudgery during harvesting is reduce as compared to local sickle which are heavier i.e. weight about 350 gm (Singh, 2007).

\section{Benefits/Advantage}

Serrated sickle needs no sherpning of cutting edge often.

Cutting efficiency is increased and cutting force is reduced.

Due to serrated edge, sharpness of blade is more efficient and has longer life than normal sickle.

Handle of serrated sickle is convenient to grip and serrated blade cuts appropriately its light weight is easy to handle.

Handle and blade are fixed with a mental sheet that provide firmness to blade while cutting and ensures safety in use.

\section{Material and Methods}

\section{Energy expenditure}

During work and rest energy expenditure was also calculated. It was done by AHR, using the regression equation given by Verghese $e t$ al., (1994).

$\operatorname{EER}(\mathrm{kj} / \mathrm{min})=0.159 * \mathrm{HR}$ (beats $/ \mathrm{min})-$ 8.72 .

\section{Physiological workload}

When an activity or a task is completed by muscular effect or physical effort, it is physiological workload. Work period is the period during which the activity was done. Recovery period is the period during which the physiological function return to resting level. At the end of the activity heart rate was also recorded. Various sickle were used to calculate value of heart rate, total cardiac cost of work (TCCW) and physiological cost of work (PCW) for wheat harvesting.

Total cardiac cost of work Physiological cost of work=

Duration of work (min)

Total cardiac cost of work $($ TCCW $)=$ Cardiac cost of work (CCW) + Cardiac cost of recovery $(\mathrm{CCR})$

$\mathrm{CCW}=$ (Average working heart rate Average resting heart rate) * Duration of work (min)

$\mathrm{CCR}=$ (Average recovery heart rate Averaged heart rate)* Duration of recovery (5 min)

\section{Classification of workload}

Workload of activity was categorized as per the following classification of workload (Table 2) in different occupations proposed by Varghese et al., (1994)

\section{Overall Discomfort Rating (ODR)}

Corlett and Bishop in 1976 developed overall discomfort rating (ODR) for the assessment $70 \mathrm{~cm}$. long graduated scale was taken with its left marked or 0 and its right end 10. 0 means no discomfort and 10 means extreme discomfort. There was a sliding pointer on the scale for discomfort marking. At the end of each trial discomfort rating was marked on the scale. All the thirty subjects gave discomfort rating which was marked on the scale. The average was calculated to get the mean rating.

\section{Rating of perceived exertion}

When there is pain there is discomfort. So gained discomfort due to pain was recorded 
while performing harvesting. So rating of perceived exertion (RPE) was determined by 5 point continuum. Very light exertion was shown as 1 and very heavy exertion was mean as 5. Mean of there was calculated for all subjects for average score.

\section{Musculo-skeletal problems}

This human body map was used. It shown musculo-skeletal problem in different body parts (Corlette and Bishop 1988) it depends on a 5 scale point very mild pain 1 to very severe pain 5 .

\section{Results and Discussion}

Physical characteristics of the participants: In the table 3 basic anthropometric data of the participants is shown.

The mean age of the selected farm women as mean on the table was 35 years. The average height was $162 \mathrm{~cm}$ and mean body weight was on the range of $42-73 \mathrm{~kg}$. The calculated mean body mass index was 22.7 which meant that they were in the normal category.

The data in table 4 mean that majority of the respondents $(73.3 \%)$ were on normal category in relation to BMI score, $10 \%$ of women had BMI score is obese grade 1 range and $16.6 \%$ women were in the range of low weight normal category.

Table 5 mean the heart rate response of all subjects during wheat harvesting using the local, the Naveen and Vaibhav sickle. It mean that the average heart rate of working female was $132.1 \pm 3.36$ beats/min by the local sickle by naveen sickle it was $127.8 \pm 2.27$ beats $/ \mathrm{min}$ and by vaibhav sickle it was $130.1 \pm 2.47$ beats/min. The heart rate in local sickle, during harvesting of wheat increased to 52.1 beats/min, in naveen sickle it was 47.2 and in vaibhav sickle it was 49.6 beats/min.
During harvesting the energy expenditure by three types of sickle rate was also noted. It varied from 9.0 to $10.7 \mathrm{kj} / \mathrm{min}$ in local sickle with mean value of $9.85 \mathrm{kj} / \mathrm{min}$. in naveen sickle it varied from 10.9 to $14.2 \mathrm{kj} / \mathrm{min}$. with mean value $11.5 \mathrm{kj} / \mathrm{min}$ and in vaibhav sickle it was 11.3 to $12.6 \mathrm{kj} / \mathrm{min}$ with mean value of $11.9 \mathrm{kj} / \mathrm{min}$.

\section{Area covered}

Vaibhav sickle covered $122 \mathrm{~m}^{2} / \mathrm{h}$ followed by $121.3 \mathrm{~m}^{2} / \mathrm{h}$ by Naveen sickle and $102.1 \mathrm{~m}^{2} / \mathrm{h}$ by local sickle.

\section{Stroke}

Maximum stroke/min was calculated Vaibhav sickle 43.8 stroke/min, followed by Naveen sickle 42.9 stroke/min and that of local sickle was 38.7 stroke/min only.

\section{Total Cardiac Cost of Work (TCCW)}

1581 cardiac beats were recorded with Naveen sickle followed by 1664 cardiac beats with Vaibhav sickle and 1738 with Local sickle. With Naveen sickle, total cardiac cost of work (TCCW) was less (9.9\%) are over the local sickle (Table 6). Singh et al., (2007) reported about improved sickle $15 \%$ saving in cardiac cost of work per unit of output was compared to local sickle.

\section{Physiological Cost of Work (PCW)}

Naveen sickle average physiological cost of work was 21.2 beats/min, for Vaibhav sickle it was 27.7 and for local sickle it was 28.9 beat $/ \mathrm{min}$. for Naveen sickle it was less $(26.4 \%)$ are the local sickle. Drudgery of farm women was reduced to $16.5 \%$ by use of improved sickle with serrated edge as concluded by Gite and Agarwal (2000) who compared it with local sickle for harvesting wheat crop. 
Table.1 Physical dimensions of sickle

\begin{tabular}{|l|l|r|r|r|}
\hline S.No & Particulars & \multicolumn{1}{|c|}{ Local } & \multicolumn{1}{c|}{ Naveen } & \multicolumn{1}{c|}{ Vaibhav } \\
\hline 1 & Total weight, $\mathrm{g}$ & 260 & 230.0 & 202.0 \\
\hline 2 & Total sickle length, cm & 30.5 & 36.0 & 35.0 \\
\hline 3 & Length of cutting edge,cm & 17.5 & 24.0 & 21.5 \\
\hline 4 & Chord length of the blade,cm & 17.9 & 21.5 & 18.0 \\
\hline 5 & Length of handle,cm & 12 & 12.0 & 13.0 \\
\hline 6 & Diameter of handle,cm & 8.0 & 10.0 & 10.0 \\
\hline 7 & Pitch of teeth,mm & 1.5 & 2.0 & 2.0 \\
\hline 8 & Radius of curvature of blade,cm & 9.8 & 13.5 & 10.0 \\
\hline 9 & Blade concavity & 3.4 & 3.6 & 4.6 \\
\hline
\end{tabular}

Table.2 Classification of workload

\begin{tabular}{|l|c|c|}
\hline Physical work load & \multicolumn{2}{|c|}{ Physiological variables } \\
\hline & Energy expenditure (KJ/Min) & Heart beats (beats/min) \\
\hline Very light & Upto 5.0 & Upto 90 \\
\hline Light & $5.0-7.5$ & $91-105$ \\
\hline Moderate & $7.6-10.0$ & $106-120$ \\
\hline Heavy & $10.0-12.5$ & $121-135$ \\
\hline Very heavy & $12.6-15.0$ & $136-150$ \\
\hline Extremely heavy & $<15.0$ & Above 151 \\
\hline
\end{tabular}

Table.3 Physical characteristics of the respondent $(\mathrm{N}=30)$

\begin{tabular}{|l|c|c|}
\hline Physical characteristics & Range & Mean \\
\hline Age in years & $21-45$ & 35 \\
\hline Height $(\mathrm{cm})$ & $147-175$ & 162 \\
\hline Gross weight in kg & $47-73$ & 59.7 \\
\hline Body Mass Index & $18.6-26.4$ & 22.7 \\
\hline
\end{tabular}

Table.4 Distribution of respondents as per BMI scores $(\mathrm{N}=30)$

\begin{tabular}{|l|c|c|}
\hline BMI Scores & Interpretation & \% \\
\hline$<16.0$ & *CED grade lll (severe) & - \\
\hline $16.0-17.0$ & *CED grade ll (moderate) & - \\
\hline $17.0-18.5$ & *CED grade l (mild) & $16.6 \%$ \\
\hline $18.5-20$ & Low weight normal & $73.3 \%$ \\
\hline $20.0-25.0$ & Normal & $10.0 \%$ \\
\hline $25.5-30.0$ & Obese grade 1 & - \\
\hline$>30.5$ & Obese grade ll & \\
\hline
\end{tabular}


Table.5 Physical cost of agricultural workers during harvesting with sickles

\begin{tabular}{|l|l|l|l|l|l|}
\hline Subjects & $\begin{array}{l}\text { Resting Heart } \\
\text { Rate } \\
\text { (beats/min) }\end{array}$ & $\begin{array}{l}\text { Working } \\
\text { Heart Rate } \\
\text { (beats/min) }\end{array}$ & $\begin{array}{l}\text { Increase in } \\
\text { Heart Rate } \\
\text { (beats/min) }\end{array}$ & $\begin{array}{l}\text { Resting Energy } \\
\text { Expenditure } \\
\text { Rate (KJ/min) }\end{array}$ & $\begin{array}{l}\text { Working Energy } \\
\text { Expenditure } \\
\text { Rate (KJ/min) }\end{array}$ \\
\hline Local & $80.1 \pm 4.37$ & $132.1 \pm 3.36$ & $52.1 \pm 4.65$ & $4.0 \pm 0.67$ & $12.2 \pm 0.55$ \\
\hline Naveen & $80.5 \pm 3.87$ & $127.8 \pm 2.27$ & $47.2 \pm 4.36$ & $4.08 \pm 0.61$ & $11.5 \pm 0.36$ \\
\hline Vaibhav & $80.4 \pm 2.55$ & $130.1 \pm 2.47$ & $49.6 \pm 3.88$ & $4.07 \pm 0.40$ & $11.9 \pm 0.41$ \\
\hline
\end{tabular}

Table.6 Physiological workload of women harvesting wheat with various sickles

\begin{tabular}{|l|l|c|c|c|}
\hline S.N0 & Parameters & Local & Naveen & Vaibhav \\
\hline 1 & Area covered, $\mathrm{m}^{2} / \mathrm{h}$ & $102.1 \pm 5.20$ & $121.3 \pm 3.62$ & $122 \pm 2.43$ \\
\hline 2 & Stroke/min & $38.7 \pm 2.34$ & $42.9 \pm 2.57$ & $43.8 \pm 2.14$ \\
\hline 3 & Cardiac cost of work(beats/min) & 26.0 & 23.6 & 24.8 \\
\hline 4 & $\begin{array}{l}\text { Total cardiac cost of work } \\
(\text { TCCW) }\end{array}$ & 1738 & 1581 & 1664 \\
\hline 5 & Physiological cost of work (PCW) & 28.9 & 21.2 & 27.7 \\
\hline
\end{tabular}

Table.7 Musculo-skelatal discomfort of women during wheat harvesting

\begin{tabular}{|l|l|}
\hline Body parts & Mean score \\
\hline Neck & 1.7 \\
\hline Shoulder & 3.0 \\
\hline Upper back & 1.6 \\
\hline Upper arm & 3.6 \\
\hline Lower back & 4.8 \\
\hline Buttocks & 1.9 \\
\hline Wrist & 2.5 \\
\hline Fingers & 3.7 \\
\hline Knee & 4.0 \\
\hline Calf & 2.0 \\
\hline Feet & 1.9 \\
\hline
\end{tabular}

Table.8 Mean value of overall discomfort rating, responses on musculo-skeletal problems and perceived exertion experienced by respondents

\begin{tabular}{|l|l|l|l|}
\hline Harvesting Method & ODR & MSP & RPE \\
\hline Local Sickle & 7.3 & $\begin{array}{l}\text { Severe pain in shoulders, upper back, hands and } \\
\text { fingers }\end{array}$ & Heavy \\
\hline Naveen Sickle & 4.2 & Moderate to light pain in shoulder, hands and arm & Moderate \\
\hline Vaibhav Sickle & 4.0 & Moderate to light pain in shoulder, hands and arm & Moderate \\
\hline
\end{tabular}

ODR - Mean value of overall discomfort rating

MSP - Musculo-skeletal problem

RPE - Rating of perceived exertion 
Fig.1 Naveen and Vaibhav improved sickles used in the study

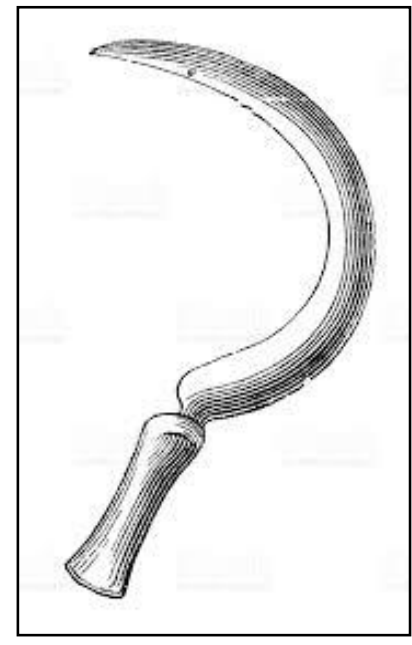

Local

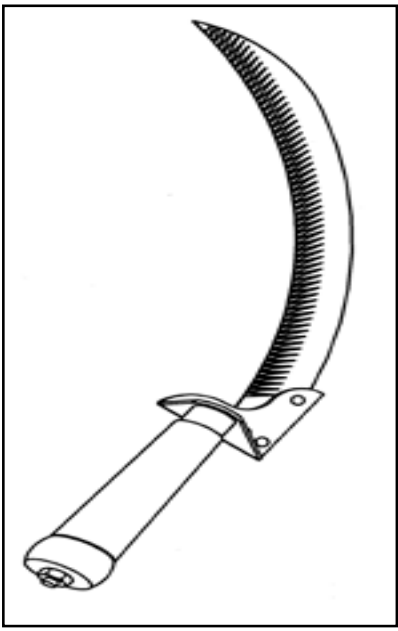

Naveen

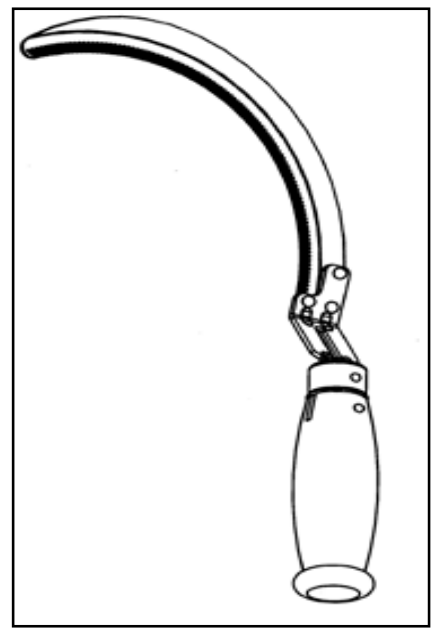

Vaibhav

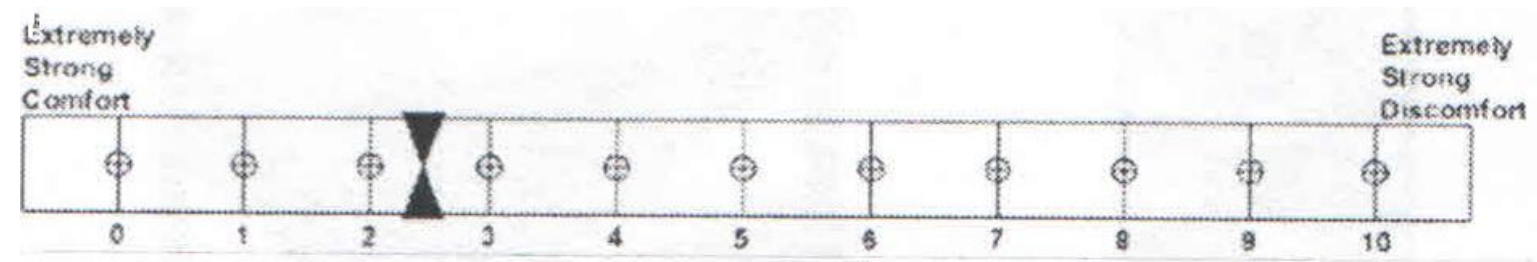

Figure B. Overall Discomfort Rating Scale

\section{Musculo-skeletal Problems}

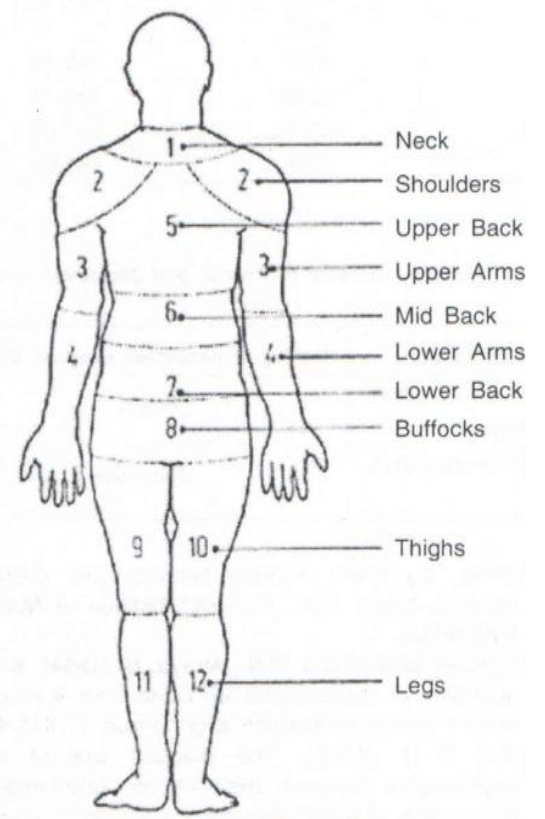

Figure C. Body map 


\section{Musculo-skeletal problems}

There are many causes of fatigue and musculo-skeletal disorders. One of them is adopting a particular posture to work for longer time, even years. It results in reduced working efficiency of the worker. Almost all the women reported to severe to moderate discomfort in lower back. The mean score was 4.8 lower back, 4.0 knee, 3.0 shoulder, upper arm 3.6, neck 1.7. All the women used traditional sickle for cutting wheat and the severe discomfort caused in palm 3.9, finger 3.7 and wrist/hand 2.5 might be due to use of traditional sickle. Field working women during harvesting reported severe pain in lower back and knee. It was because of working for long duration in squatting posture (Jyotsna et al., 2005) (Tables 7 and 8).

\section{Overall Discomfort Rating (ODR)}

The activity of harvesting wheat consumes lot of time and performed for long hours continuously. It results is pronounced musculo-skeletal problems.

\section{Rating of perceived exertion (RPE)}

The rating of perceived exertion was heavy in local sickle but light to moderate after the use of Naveen and Vaibhav sickle.

General discussion was conducted after completing the study to receive the feedback for improved method (Naveen sickle and Vaibhav sickle) and old method (local sickle) with farm women. In the discussion it was stated that local sickle is very heavy due to heavy handle. It cover less area require more time and labour for harvesting the crop.

Working in squatting posture for long period create more skeletal problems and leads to body hazards to the particulars ladies. Farm women told several positive points regarding improved method (Naveen sickle and Vaibhav sickle). They all said that Naveen and Vaibhav sickle were easy to handle due to light weight which was the leading point.

Another important point was that it cuts the crop from bottom level. This helps to avoid burning problem of residues at the field. The serrated blade cut the crop sharply and covers more area in less time that saves time and money. It also minimizes the muscular problems of body.

These finding clearly show that improved farm equipments that are women friendly are better in every respect in harvesting the crop. Naveen sickle, as the results show, is better than the local sickle. It cover more area in given time, minimizes the drudgery and the perceived exertion was also low. It saves time and money expenditure on labour. It is very easy to handle and body problems are less. Only drawback noted was that left handers can't use it. One important point that emerged from the end users was that these advanced technologies should be adopted by the farm women but it will take time to reach it at rural area. Great efforts are needed for new technologies to practice in rural area.

\section{References}

Corlett, E.N., and Bishop, R.P. 1976. A technique for assessing postural discomfort, Ergonomics, 19: 175-182.

Garrow, J., 1987. Human nutrition and dietetics. Nutrition news 1991. National Institute of Nutrition, Hyderabad.

Gite, L.P., and N. Agarwal 2000. Ergonomical comparison of local and improved sickle for wheat harvesting by women workers. Agricultural Engineering Today, 24(3): 7-12.

Jyotsna, K.R., Singh K, Mehta M 2005. Ergonomic evaluation of the rural women while performing wheat 
harvesting activity. J Hum. Ecol. 18(4):309-311.

Jyotsna, Kusum Rana and Mamta Dilbaghi. 2014. Occupational constraints analysis of women engaged in wheat harvesting. Stud. Home Com Sci, 8(1): 53-58.

Khan M, Sajjad M, Hameed B, Khan MN, Jan AU (2012). Paeticipation of women in agriculture activities in district Peshawar. Sarhad Journal of Agricultyre. 28(1):121-127.

Kumar Bharat P.P., Govinda, Gowda. V., and Khandekar, Neeta (2011). Time utilization pattern and drudgery of horticulture farmers. International Journal of Engineering and Management Sciences. 2(2): 93-96.

Prakash N, Rishikanta Singh Kh, Punitha P.S.S.Roy, M.A.Ansari and S.V.Ngachan (2014). Gender mainstreaming in small farm production system. Souvenir: $7^{\text {th }}$ National Extension Education Congress in Umiam, Meghalaya.

Rajendran Poornima and Lokandha Reddy. (2013). Ergonomics in agricultural education. Cognitive Discourses International Multi disciplinary Journal ISSM 2321-1075. Vol.1, Issue 1 July.
Sharma Barkha, S.R.K. Singh, S. Gupta, M.K.Shrivastava and Shilpi Verma. (2015). Improving efficiency and reduction in drudgery of farm women in weeding activity by twin wheel hoe. Indian Res.J.Ext. Edu. 15(1), January.

Singh Alka, U.S.Gautam, Rajesh Singh and Dinesh Paliwal. (2014). Ergonomic study of farm women during wheat harvesting by improved sickle. African Journal of Agricultural Research. Vol 9(18) pp. 1386-1390.

Singh S.P., Gite L.P., Agarwal Nidhi and Majumdar J. (2007). Women friendly improved farm tools and equipment. Central Institute of Agricultural Engineering, Bhopal.

Singh Surabhi and Renu Arora (2010). Ergonomic intervention for preventing musculoskeletal disorders among farm women. J.Agri Sci, 1(2): 61-71.

Singh, S.P., 2009. Physiological workload of farm women while evaluating sickle for paddy harvesting.

Varghese, M.A., Saha, P.N., Atreya, N. (1994). A rapid appraisal of occupational workload from a modified scale of perceived exertion. Ergonomics, 37: 485-491.

\section{How to cite this article:}

Barkha Sharma, Shilpi Verma and Md. Mustafa. 2017. Ergonomic Evaluation of Drudgery Load Faced by Farm Women in Wheat Harvesting. Int.J.Curr.Microbiol.App.Sci. 6(10): 30143022. doi: https://doi.org/10.20546/ijcmas.2017.610.355 